\title{
Developing of a Learning Media for Smartphones for Disaster Mitigation Education
}

\author{
https://doi.org/10.3991/ijet.v16i07.21195 \\ Neni Wahyuningtyas, I Nyoman Ruja, M. Haris Yahya \\ Universitas Negeri Malang, Malang, Indonesia \\ Daya Negri Wijaya $\left({ }^{凶}\right)$ \\ University of Porto, Porto, Portugal \\ dayawijaya15@yahoo.com \\ Mohd Hairy Ibrahim \\ Sultan Idris Education University, Tanjong Malim, Malaysia
}

\begin{abstract}
Disaster preparedness is an absolute prerequisite for the development of disaster risk reduction. This means that there is no awareness of danger disaster, then the high possibility of both physical and material losses is an inevitable matter. It is a must for humans to be sensitive and care for various possible disasters that can occur in the vicinity stay. Education on disaster mitigation needs to be introduced to the community. This is important to create residents who are responsive and ready for disaster. This paper aims to develop learning media supported by the use of smartphones to increase literacy about volcanic eruption disaster mitigation. This study using research and development with the 4D model. The results of this development are mobile encyclopedia packaged in a smartphone application as a media for volcanic eruption disaster mitigation education. Media and material validation show that the product being developed is very good and worth testing. Besides, the results of media validation by indicator: attracting attention, interactivity, presentation of learning material, feedback, quality of learning, training showed benefits and students were enthusiastic in learning using this media. This product can be an alternative media for the $21^{\text {st }}$. century that applies mobile in the learning process.
\end{abstract}

Keywords-Media, mobile learning, disaster mitigation

\section{$1 \quad$ Introduction}

Indonesia is one of the countries that have a high risk of volcanic eruption disaster. This is due to the geographical reason for Indonesia, which is located on the Ring of Fire area [1]. This phenomenon will have an impact on the areas that are traversed so that the intensity of volcanic eruption disaster will increase. According to Badan Nasional Penanggulangan Bencana (BNPB) [2] during 2018, a number of 1,999 disasters were recorded in Indonesia. The impact caused by the disaster was reported to be enormous. It was recorded that 3,548 people died and disappeared, 13,112 people 
were injured, 3.06 million people were displaced and affected by the disaster, 339,969 houses were severely damaged, 7,810 houses were moderately damaged, 20,608 houses were slightly damaged and thousands of public facilities were damaged. It is estimated that the frequency of natural disasters for example volcanic eruption in Indonesia will tend to increase in the future.

Disaster preparedness is the main step to reduce disaster risk. This means that without awareness of the dangers of disasters by humans, there is a great risk of physical and material damage. Sensitivity and concern is a necessity for humans to possible disasters that can occur in their neighborhood.

Educational activities about volcanic eruption disaster mitigation need to be introduced to the community from an early age, including for students at the junior high school level. This is important in the effort to create citizens who are responsive and ready for disasters.

Examples of cases of implementing disaster mitigation as illustrated are between the two countries that have similar disaster cases and geographic ranges, namely between Fiji and Japan where the volcanic eruption disaster occurred but the two countries had very different impacts and the number of victims [4]. In Fiji, almost the entire population died while in Japan almost the entire population survived. This phenomenon occurs because Japan has long been aware of the vulnerability of disasters in its region so that they have built infrastructure and a culture that is responsive to disasters in the lives and education of its people so that when a disaster occurs, this community will understand the greatest actions and efforts that can be taken to decrease the impact of the disaster raised. We all know that Japan is very concerned about disaster mitigation. From an early age, Japanese children are introduced to how to adapt to the disasters that surround them. Through various media in schools, they explained and simulated disaster risk reduction actions intensively.

Learn from Japan's valuable experiences, it is very appropriate to use learning media as an educational medium for volcano eruption disaster mitigation for students. Various learning media can be used as a choice. A smartphone is one of the potential media to be used. The use of smartphones today is possible due to the times where mobile technology facilities have developed rapidly, and human life cannot be separated from digital things [5]. It cannot be denied, that almost everyone has their smartphone, including students.

To take advantage of these opportunities, researchers are interested in developing educational media for volcano eruption disaster mitigation through a smartphone-based mobile encyclopedia. The media content developed refers to the basic competencies of the Social Studies Subject "Understanding the Concept of Space (Location, Distribution, Potential, Climate, Shape of the Earth, Geology, Flora, and Fauna) and Inter-Spatial Interaction in Indonesia and Its Effects on Human Life in Social Aspects, Culture, and Education". The media produced in principle has good flexibility, considering that the media is developed using an online app builder and the final product can be run on smartphones with a minimum Android OS version 4.0.0 (Jelly Bean), tablet phones with similar specifications. 


\section{$2 \quad$ Method}

The research design used the Research and Development (R\&D) method. $R \& D$ as a research method that is deliberate, systematic, aimed or directed to seek, find, formulate, improve, develop, produce, test the effectiveness of products, models, methods, strategies, certain procedures, new effective, efficient, productive, and productive [7]. Meanwhile, the model used in this research and development is the basis for research and development of the 4-D model. The reason for choosing this model is that the reason this model is suitable for use is that it is more detailed, simple, and systematic. This can be seen clearly at each stage of development that researchers must do. So, the research model is expected to help facilitate the process of developing a smartphone. Based on Mobile Encyclopedia as a structured disaster mitigation education media.

4D's model consists of four stages, namely: define, design, develop, and disseminate [8].

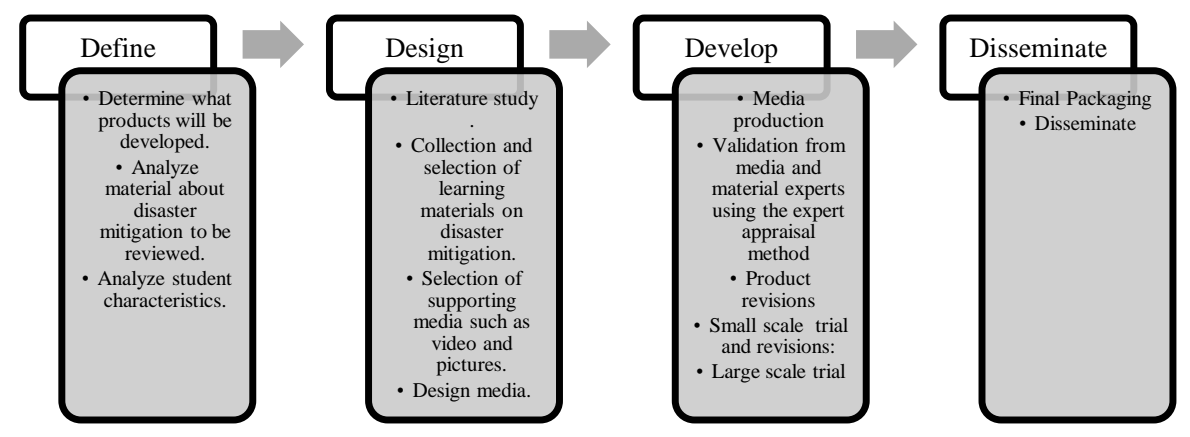

Fig. 1. 4D models

Based on the product development design, the production stages explained as follows:

\subsection{Define}

The definition stage has activities to determine what products will be developed. At this stage, the orientation of the problem behind the research is described, identified, and formulated so that alternative solutions can be found. Based on the objectives that have been previously described, that is the media product to be developed is a smartphone-based mobile encyclopedia. This application is an encyclopedia that is accessed by a mobile device that contains material disaster mitigation. The next step the researcher took was analyzing the material and student characteristics. Analyzing this 
material is an important activity to determine the depth and breadth of the material to be discussed. Disaster mitigation materials are chosen considering that Indonesia is a disaster-prone area and has become an obligation to understand that. Therefore, it is hoped that the people who live in disaster-prone areas have disaster mitigation education and disaster response which threatens his life. After material analysis, the researcher examines the characteristics of students such as students 'prior knowledge, students' cognitive development, and data about the effective development of students as an illustration for developing a mobile encyclopedia. The final step in the define stage is the formulation of learning objectives. The essence of this step, namely formulating indicators and learning objectives based on material analysis and student characteristics. Detailed indicators and objectives this learning is the basis for further compiling media content.

\subsection{Design}

The activities design stage is as follows:

A literature studies: This step is the first step that bridges the define stage and the stage design as a continuation of the formulation of learning objectives. Study literature conducted by researchers, namely by searching for various sources written, whether in the form of books, archives, articles, and journals, or documents that are relevant to the material to be reviewed. So that the information obtained from the study. This literature is used as a reference to strengthen the concept of disaster mitigation materials which is the content of the mobile encyclopedia development.

Collection and selection of materials: In this step, the researcher collects and selects the appropriate material student topics and characteristics. So that there are several principles guided by researchers namely: the principle of relevance means linkage. Learning material must be related to the achievement of competence. That matter developed must have consistency with the learning objectives that have been formulated at the beginning. The principle of sufficiency means that the material covered should be sufficient adequate in helping students master the basic competencies being taught.

Collect and select media: The selection of supporting media is carried out to determine which media is suitable for the content of the material presented. This supporting media selection process is adjusted accordingly with material analysis or learning content, and student characteristics. The existence of supporting media such as videos can concrete students' understanding accommodate the various modalities that students have.

\subsection{Design}

The purpose of the development stage is to produce a product based on suggestions from experts as validators and the data obtained. The activities carried out at this stage are: (1) Media production, the stage of making media according to the predetermined design, namely the define and design stage. (2) Expert Validation, validation is carried out on media products that have been developed. This product will be validated by 
experts such as material and media experts so that it can be seen the service of a product to be tested and used by students. The validation data collected were analyzed using the following formula. Meanwhile, product eligibility is based on the table 1 .

Table 1. The Criteria for Instrument Eligibility

\begin{tabular}{|c|l|}
\hline Percentage (\%) & \multicolumn{1}{|c|}{ Information } \\
\hline $80-100$ & Very good (No revision) \\
\hline $66-79$ & Good (Minor revision) \\
\hline $56-65$ & Fair (Mayor revision) \\
\hline $40-55$ & Poor (Revision and redesign material content) \\
\hline $0-39$ & Bad (Rejected) \\
\hline
\end{tabular}

Source: [9]

Info:

$\mathrm{P} \quad=$ Percentage

$\sum x=$ Total Response

$\sum x \mathrm{i}=$ Total Ideal

$100 \%=$ Constant Number

(3) Revision, this activity aims to improve the media that has been produced based on the results of advice and suggestions for improvement as well as the evaluation of material and media expert validates. If the validation results have been declared possible, the media can be tried out on students. (4) Trials and revisions, this trial aims to get a direct response from students on the media being developed. The results of this trial will be used to revise the media prototype to produce the last prototype that has been tested for quality and effectiveness.

\subsection{Disseminate}

The dissemination is the stage of publication or dissemination of products that have been tested for quality and effectiveness for the benefit.

\section{Result}

\subsection{Product specification}

The product developed in this learning media is an electronic encyclopedia of volcanic eruption disaster mitigation. This media is produced as an application that can be operated on a smartphone with a target of achievement which has a description of subject matter about disaster mitigation, pictures, and practice questions to measure student's competence to understood disaster problems in their surroundings. These media are also equipped with contextual multimedia such as pictures and videos.

The mobile learning design is expected to offer new experiences to students. The concept of mobile learning is intended as an effort to give learning materials through 
electronic-based media. With this, students can reach it anytime and from anywhere from all corners of the world. Flexibility is the keyword in this mobile learning system. Students can freely choose the time and place to study. They don't have to come somewhere at a certain time. On the other hand, teachers can update their learning materials anytime and from anywhere. In terms of content, learning materials can be made very flexible, starting from text-based material, images, to learning material in a multimedia video.

\subsection{Product description}

The product description developed in the form of an application has the following features.

1. Beranda (Home): This menu display contains the header of the application name and menus consisting of several buttons that can be accessed according to the user's wishes. The following is an initial view of the application being developed.

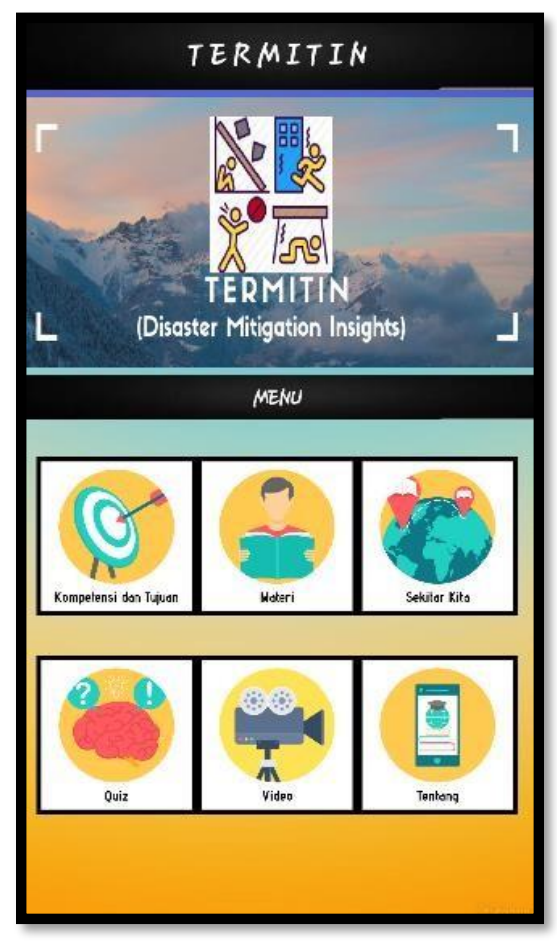

Fig. 2. Beranda (Home) Menu

2. Kompetensi dan Tujuan (Competency and Objectives): This menu contains information related to Core Competencies (Kompetensi Inti), Basic Competencies (Kompetensi Dasar), and Learning Objectives (Tujuan Pembelajaran). Through this 
menu, the teacher or student can see what competencies must be achieved in learning.
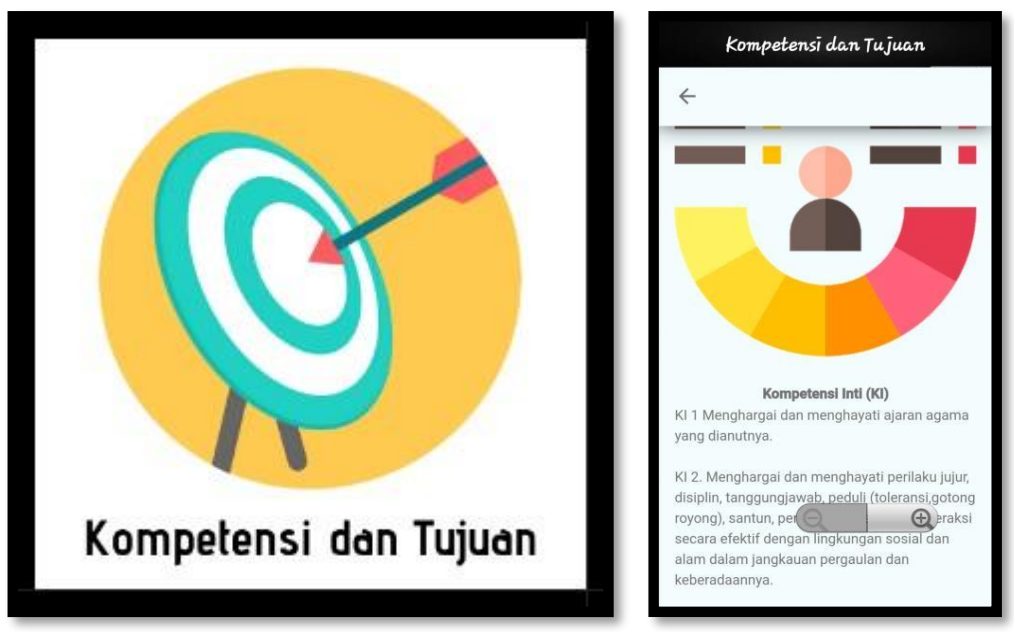

Fig. 3. Kompetensi dan Tujuan (Competency and Objectives) Menu

3. Materi (Materials): This menu contains several choices of general materials related to learning which include: Natural Disasters, Characteristics of Natural Disasters, Disasters in Indonesia, Disaster Mitigation, and Mitigation Measures. This general material outlines the definition of concepts related to disaster and mitigation.
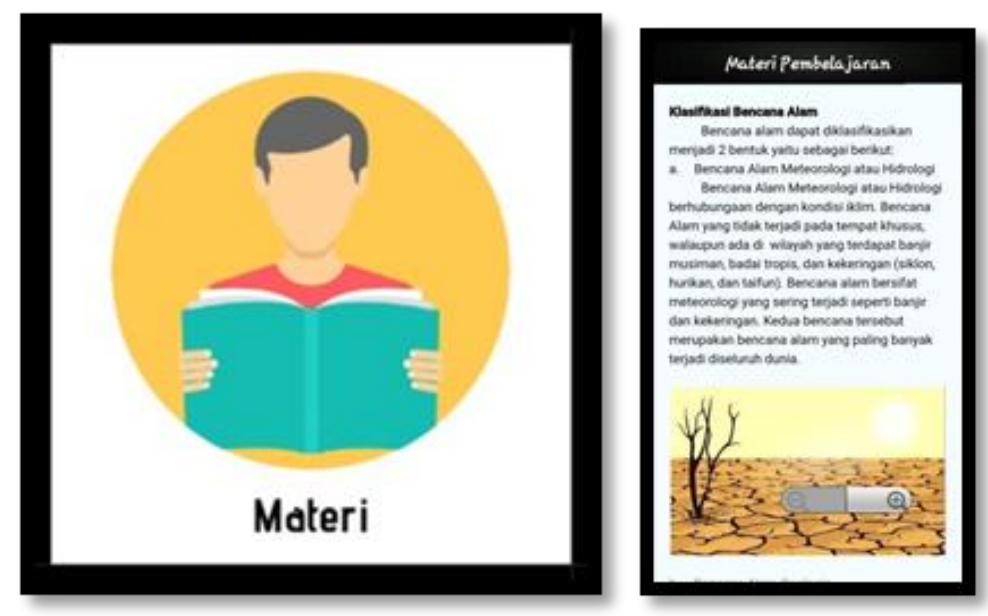

Fig. 4. Materi (Materials) Menu

4. Sekitar Kita: "Sekitar Kita" means around us, this menu contains contextual material that supports the learning process. The contextual material in question includes 
everything related to the object of the development study, namely Mount Kelud which is located in the Blitar Regency. How the Mount Kelud erupted in all years and their mitigation is explained in this menu.
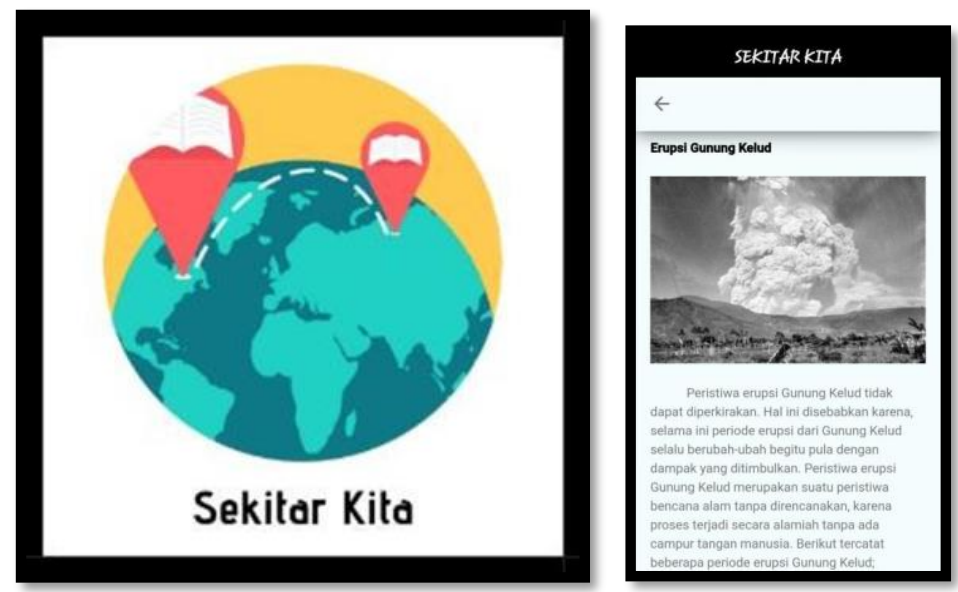

Fig. 5. Sekitar Kita (Around Us) Menu

5. Video: This menu contains learning videos that are relevant to the material. The purpose of the inclusion of video is to facilitate student modalities and concrete students' understanding of the material. This becomes important because students have various modalities and characteristics. To make it easier for them to learn the material, it needs to be supported by an audiovisual display such as video and pictures related to learning materials.
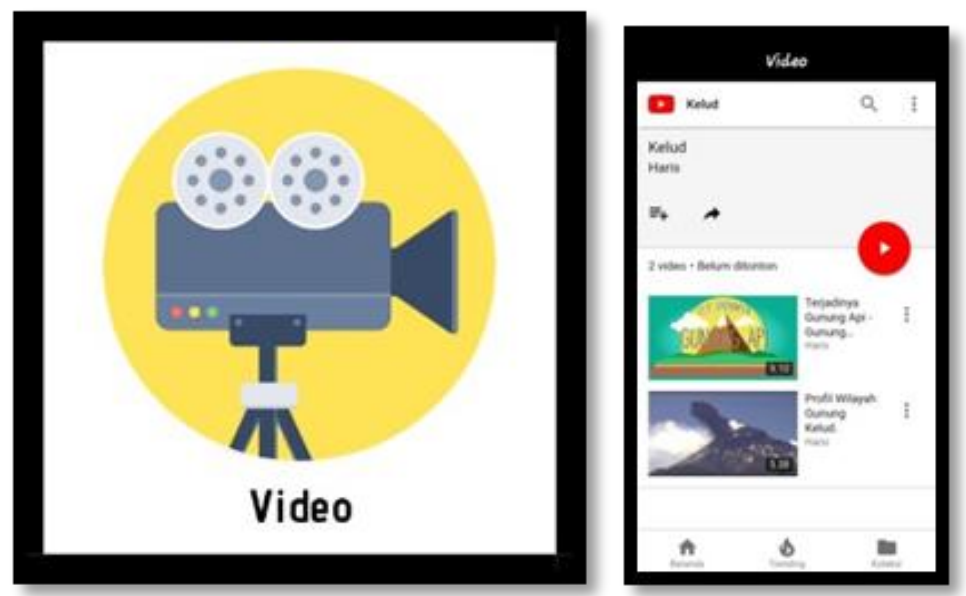

Fig. 6. Video Menu 
6. Quiz: This menu contains learning evaluation questions. This quiz can be played by students after studying on the material menu. The quiz feature serves as an evaluation for students after completing learning.
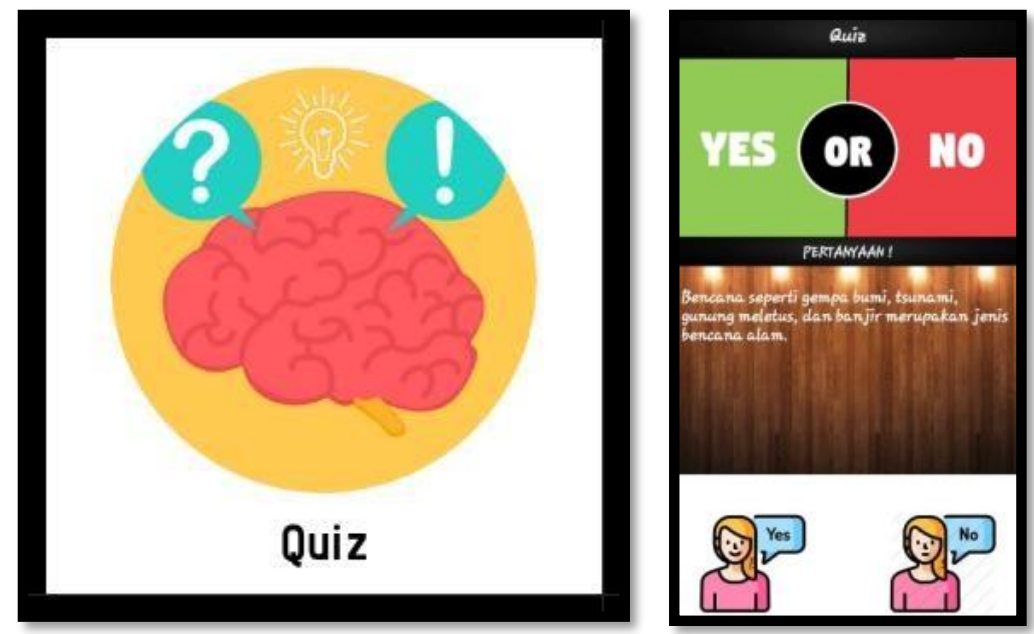

Fig. 7. Quiz menu

7. Tentang: Tentang means about, this menu contains a description of the identity of the application developer.
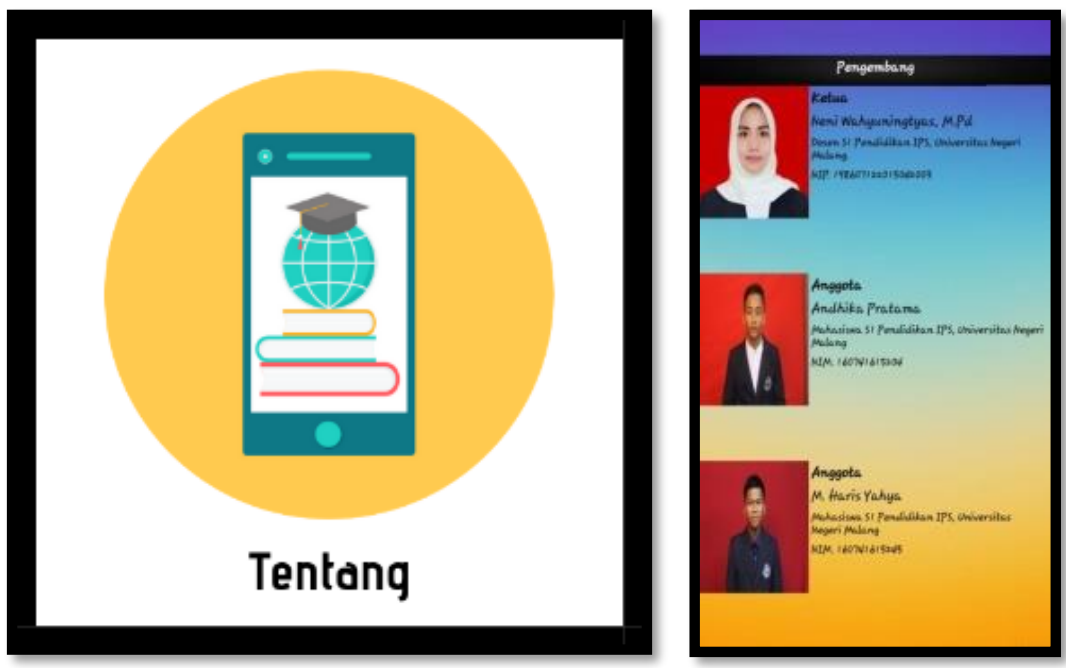

Fig. 8. Tentang (About) Menu 


\subsection{The result of the validation}

Validation data were obtained from assessments and reviews by media and material experts. The assessment is carried out using a media expert questionnaire and a material expert questionnaire to get an assessment of the product that has been developed. Based on the results of the validation, the following data were obtained.

1. Media: Media product validation was assessed by an expert validator, Fatiya Rosyida, M.Pd. She is a lecturer in the Faculty of Social Sciences, Universitas Negeri Malang who is concerned with learning media. The results of this learning media validation are as follows in Fig 9.

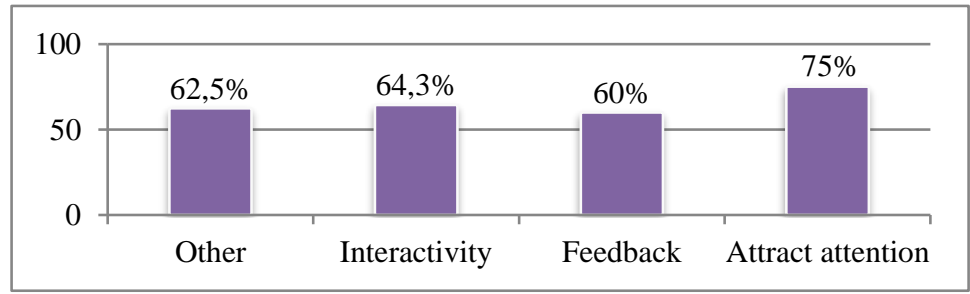

Fig. 9. Media expert validation results

The results of the validation from the media expert produced good criteria with a feasibility value of $66.7 \%$. Based on the suggestions of the media validator, a revision of the developed media product is required and then re-validated the media. The following is the average result based on the aspect of the material of attract attention to get a percentage value of $75 \%$; feedback aspect get percentage value of $60 \%$; the interactive aspect get a percentage value of $64.3 \%$ and for other aspects get percentage value of $62.5 \%$.

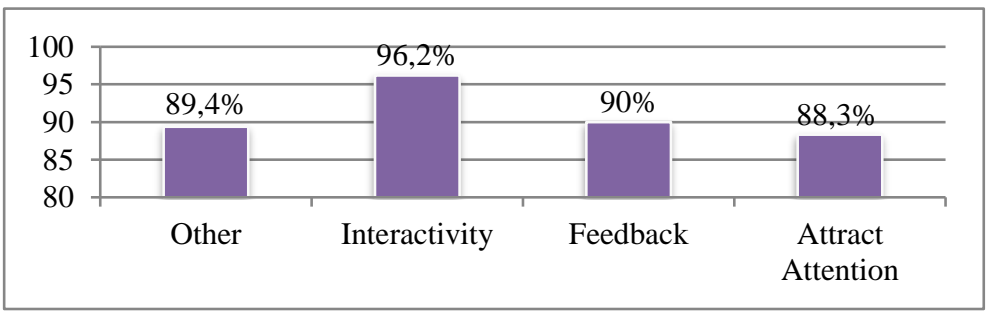

Fig. 10. Media expert validation revision results

After the learning media was revised, it was re-validated. The results of the second validation, the value is $90.23 \%$ and it belongs to the very good criteria. Based on these results, it can be said that the media developed is feasible to be tested on the next stage. The following is the result of the score based on the aspect of the material that attracting attention-getting a score of $88.3 \%$; the feedback aspect gets a percentage score of $90 \%$. The highest score was found in the interactivicity aspect, namely $96.2 \%$ and other aspects got a percentage value of $86.4 \%$. 
2. Materials: The next step is to validate the learning material aspect. This validation aims to assess whether the material developed has been appropriate and in accordance with existing rules and concepts or not. The material validator is Ninja Panju Purwita, M. Pd. She is a lecturer who teaches at the Department of Social Studies at the Faculty of Tarbiyah UIN Maliki Malang. Based on the results of the validator assessment, the following results were obtained:

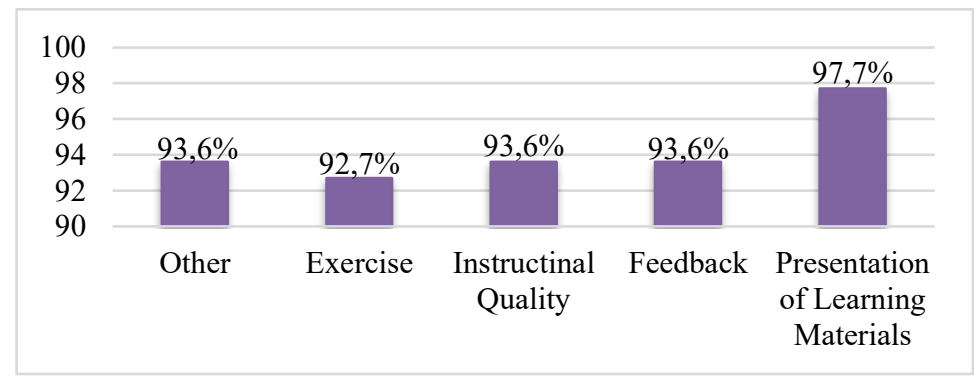

Fig. 11. Material expert validation results

Based on the validation results from material experts, the criteria were very good with an average value of $94.24 \%$. The following details the results of the material expert's validation based on the aspects of the presentation of the material, obtaining a percentage score of $97.7 \%$. The aspects of feedback, instructional quality, and others get the same score, namely $93.6 \%$. At the same time, aspect of exercise obtained a percentage value of $92.7 \%$.

\subsection{Implementation}

To determine the effectiveness of the Mobile Encyclopedia product that has been developed, the results of the media development need to be tested. The trials conducted in this study consisted of two stages, namely small scale trial and large scale trial. The location for the trial is at SMP Negeri 1 Gandusari. The results of the trial are as follows:

\section{Small scale trial}

Retrieval of data on a small scale trial involved 10 students of class VIIC at SMP Negeri 1 Gandusari. The results of this limited test are to get input from media products that have been developed. Following are the results of the limited-scale field trials that have been carried out: 


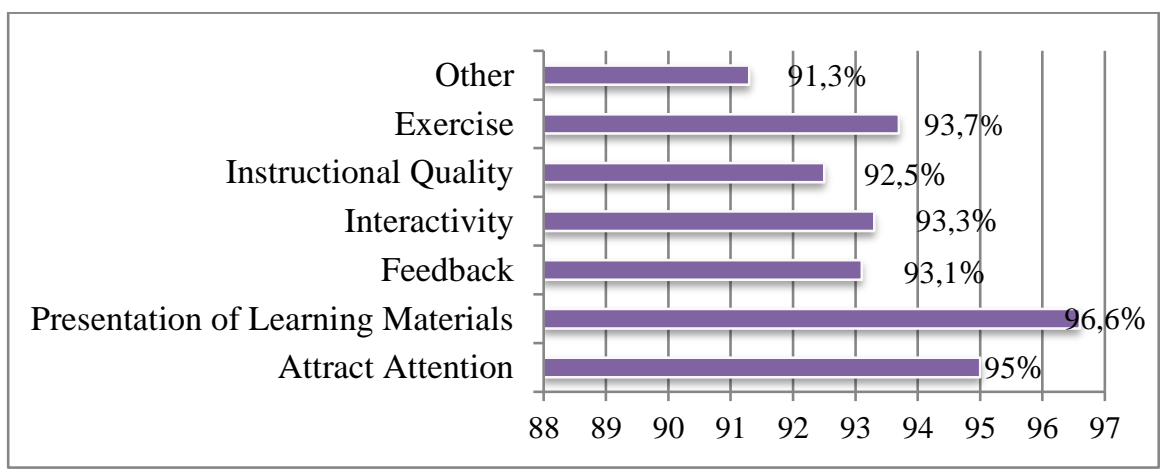

Fig. 12. Small scale trial results

Based on the results of the questionnaire item analysis, it was found that the small scale trial at SMP Negeri 1 Gandusari had an average percentage value of $93.64 \%$ which was considered very good. The details of the average value are obtained from the aspect of the material of interest which gets a percentage value of $95 \%$. The highest aspect is obtained from the material presentation aspect which gets a percentage value of $96.6 \%$. Other aspects such as the feedback aspect get a percentage of $93.1 \%$, the interactive aspect of $93.3 \%$, the exercise aspect get a percentage of $93.7 \%$, and other aspects get a percentage of $91.3 \%$. Referring to the results of this small scale trial, large scale trial was carried out according to the research and development stages.

\section{Large scale trial}

Large scale field trials were carried out on 35 class VII. B students at SMP Negeri 1 Gandusari. Based on the data analysis from the results of the large-scaletrials, the following results were obtained:

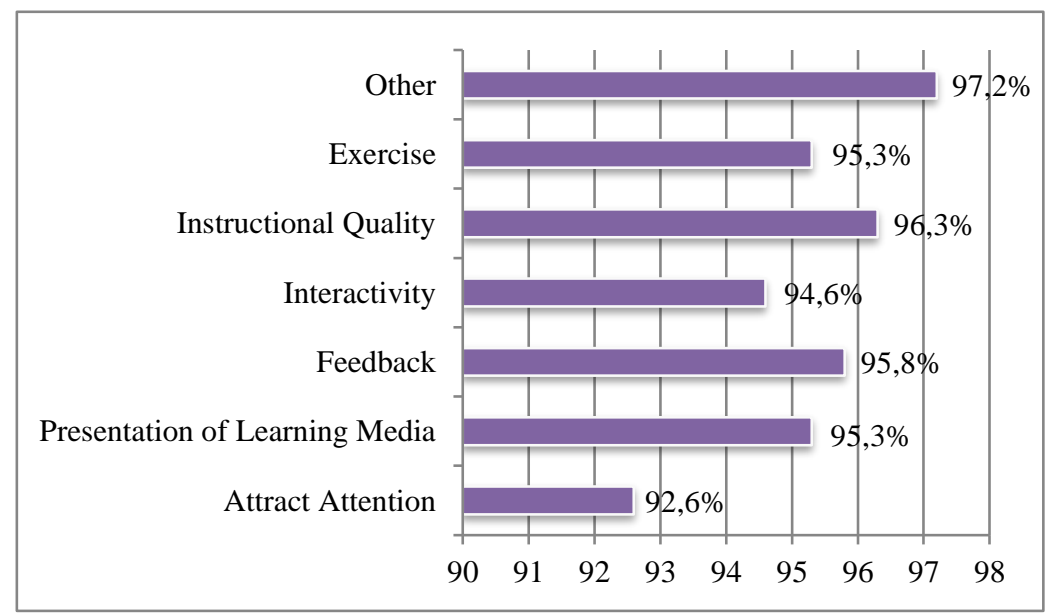

Fig. 13. Large scale trial results 
The results of large scale trials at SMP Negeri 1 Gandusari obtained very good criteria with a percentage value of $95.3 \%$. The details of the results, namely other aspects obtained the highest percentage value of $97.2 \%$. The instructional quality aspect obtained a percentage value of $96.3 \%$, then the feedback aspect got a value of $95.8 \%$, the material presentation aspect was $95.3 \%$, the practice question aspect was $95.3 \%$, the interactive aspect got a percentage of $94.6 \%$, and aspects of the attention-grabbing material of $92.6 \%$. Based on these results, it can be concluded that the smartphonebased mobile encyclopedia is very effective as a disaster mitigation Education in junior high school level.

\subsection{Discussion}

Indonesia is a country that has a high risk of volcanic eruption disaster. Volcanic eruption disaster mitigation education needs to be introduced to the community from an early age. One of the strategies that can be used in providing education related to volcanic eruption disaster mitigation among students is through learning media. Smartphone are a potential medium to use. It must be recognized in this $21^{\text {st }}$ Century learning media based ICT provide great benefit [5]. Innovative learning media is one of the factors that can motivate students to learn and be able to encourage them to achieve maximum learning outcomes [10]. Therefore, integrating the use of Information Communication Technology (ICT) in learning becomes urgent to provide a fun way of learning and also to form an effective learning environment [11], [16].

Education has a strategic role in human life, therefore the implementation of education by schools should not only give knowledge transfer but can make learning meaningful. The paradigm of modern education is to make educators not merely transferring knowledge, but rather as facilitators and motivator [12]. Learning will become more meaningful when students are actively involved in discovering the concept of phenomena in the environment [13], especially if it is added with the knowledge and student experience. Mobile-based learning can be a solution to support teaching and learning activities to be more effective, efficient, and real-time. Through usage like learning, mobile apps can help the learning process becomes practical and flexible [5]. In addition to meaningful learning, learning is also expected to provide $21^{\text {st }}$ century learning skills.

Volcanic eruption disaster mitigation is one part of the skills for student life, especially students who live in disaster-prone areas because volcanic eruption disaster mitigation is part of skills that can be applied in student life. This is after the general, principles of curriculum development in schools should be adapted to the demands, needs, and development of society [14]. Learning can be adapted to the needs of the environment; therefore, the material on volcanic eruption disaster mitigation can be used as one of the local content materials for schools' areas. Disaster mitigation materials are very proper to be included in the educational curriculum. School is an effective vehicle in providing the effect of transmitting information, knowledge, and skills to the peoples. However, disaster education activities in schools become an effective, dynamic, and sustainable strategy to send disaster mitigation education [15]. 


\section{Conclusion}

Mobile Encyclopedia is an application that can be operated on a smartphone with a target of achievement which has a description of subject matter about disaster mitigation, pictures, and practice questions to measure students competence to understood disaster problems in their surroundings. These media are also equipped with contextual multimedia such as pictures and videos. The mobile learning design is expected to offer new experiences to students. The concept of mobile learning is intended as an effort to give learning materials through electronic-based media. With this, students can reach it anytime and from anywhere from all corners of the world. Flexibility is the keyword in this mobile learning system. Students can freely choose the time and place to study. In terms of content, learning materials can be made very flexible, starting from text-based material, images, to learning material in a multimedia video.

\section{Acknowledgement}

I would like to thank my fellow lecturers and students who helped in this research.

\section{References}

[1] N. Wahyuningtyas, N \& L. Febrianti, L \& F. Andini. (2020). The carrying capacity of GIS application for spatial thinking growth in disaster material". IOP Conference Series: Earth and Environmental Science. 485. 012018. https://doi.org/10.1088/1755-1315/485/1/012018

[2] Badan Nasional PenanggulanganBencana (BNPB). (1999). KejadianBencanaSelamaTahun 2018, Ribuan Korban Meninggal Dunia. (Online) https://bnpb.go.id/berita/1999-kejadianbencana-selama-tahun-2018-ribuan-korban-meninggal-dunia

[3] Maryani, E. (2016). Model PembelajaranMitigasiBencanadalamIlmuPengetahuanSosial di SekolahMenengahPertama. JurnalGeografiGea 10(1). https://doi.org/10.17509/gea.v10i1. $\underline{1664}$

[4] Hermanto, Fery. (2014). Pengembangan LKS IPA Discovery BerdasarkanKurikulum 2013 MateriMitigasiBencanauntukSiswa Kelas VIII SMP." Pensa: Jurnal Pendidikan Sains, Vol. 2, No. 02, 2014.

[5] I. W. P. Utami, I. Lutfi, S. S. P. Jati, M. Y. Efendi. (2019). Effectivity of Augmented Reality as Media for History Learning. Int. J. Emerg. Technol. Learn. IJET, vol. 14, no 16, pp. 83-96. https://doi.org/10.3991/ijet.v14i16.10663

[6] KementrianRiset dan Pendidikan Tinggi. (2017). Smartphone Rakyat Indonesia. (Online), https://ristekdikti.go.id/smartphone-rakyat-indonesia

[7] Putra, Nusa. (2011). Research \& Development Penelitian dan Pengembangan: SuatuPengantar. Jakarta: PT Raja GrafindoPersada.

[8] Thiagarajan, S., Semmel dan Semmel. (1974). Instructional Development for Training Teacher of Exceptional Children. Minnesota: Indiana University.

[9] S. Arikunto. (2014). ProsedurPenelitian: SuatuPendekatanPraktik. Jakarta: RinekaCipta.

[10] N. Ratnawati, S. Sukamto, I Ruja, N. Wahyuningtyas. (2020). "Defense of the Ancients", Gamification in Learning: Improvement of Student's Social Skills. Int. J. Emerg. Technol. Learn. IJET, vol. 15, no 7, pp. 132-140. https://doi.org/10.3991/ijet.v15i07.13221 
[11] N. Wahyuningtyas. (2019). Developing Edmodo-Based Online Learning Media to Support Student's Skill of Social Studies In 21th Century. IOP Conference Series: Earth and Environmental Science, Jember, 2019, vol. 243, p. 012160. https://doi.org/10.1088/1755$1315 / 243 / 1 / 012160$

[12] N. Wahyuningtyas, Idris. (2020). Increasing Geographic Literacy through the Development of Computer Supported Collaborative Learning. Int. J. Emerg. Technol. Learn. IJET, vol. 15, pp. 74. https://doi.org/10.3991/ijet.v15i07.13255

[13] Rizal, M. (2014). PengaruhPembelajaranInkuiriTerbimbingdengan Multi RepresentasiterhadapKeterampilan Proses Sains dan PenguasaanKonsep IPA Siswa SMP. Jurnal Pendidikan Sains, 2(3), 159-165.

[14] Syaodih, Nana. (2013). PengembanganKurikulum. Bandung: PT RemajaRosdakarya.

[15] Konsorsium Pendidikan Bencana. (2011). KerangkaKerjaSekolahSiagaBencana. Jakarta.

[16] Š. Bagon, M. Gačnik, A. I. Starcic. (2018). Information Communication Technology Use among Students in Inclusive Classrooms. Int. J. Emerg. Technol. Learn. IJET, vol. 06, pp. 56-72. https://doi.org/10.3991/ijet.v13i06.8051

\section{Authors}

Neni Wahyuningtyas is a lecturer in Faculty of Social Science, Universitas Negeri Malang, Indonesia. She is majoring in Geography and mastering in learning media and related information technology in education. Email: neni.wahyuningtyas.fis@um.ac.id

I Nyoman Ruja is a lecturer in Faculty of Social Science, Universitas Negeri Malang, Indonesia. $\mathrm{He}$ is interested in learning innovation. Email: nyoman.ruja.fis@um.ac.id

M. Haris Yahya is a student in Faculty of Social Science, Universitas Negeri Malang, Indonesia. He is majoring in Social Studies Education and interested in learning innovation. Email: m.haris.yahya.1607416@students.um.ac.id

Daya Negri Wijaya is a PhD student in History, University of Porto, Portugal. He is lecturer in Faculty of Social Science, Universitas Negeri Malang and interested in history. Email: dayawijaya15@yahoo.com

Mohd Hairy Ibrahim is a lecturer in Faculty of Human Science, Sultan Idris Education University, Malaysia. He is majoring in Geography \& Environment and interested in Physical Geography. Email: m.haris.yahya.1607416@students.um.ac.id

Article submitted 2021-01-15. Resubmitted 2021-02-24. Final acceptance 2021-02-25. Final version published as submitted by the authors. 